\title{
Alopecia Areata and Toxic Metals
}

\author{
Paolo Daniele Pigatto ${ }^{a}$ Silvia Mariel Ferrucci ${ }^{b} \quad$ Lucia Brambilla $^{b}$ \\ Gianpaolo Guzzic
}

${ }^{a}$ Clinical Dermatology, IRCCS Istituto Ortopedico Galeazzi, Department of Biomedical, Surgical and Dental Sciences,

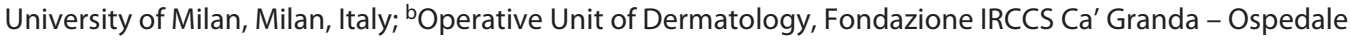
Maggiore Policlinicoo, Milan, Italy; ' Italian Association for Metals and Biocompatibility Research - A.I.R.M.E.B., Department of Dental Toxicology, Milan, Italy

\section{Keywords}

Acquired hair loss · Alopecia universalis · Humans · Metals poisoning $\cdot$ Zinc deficiency

\section{Abstract}

Toxic metals are not so rare but are often neglected causes of alopecia areata in men and women. Thallium, arsenic, selenium, and mercury are the most common cause of metalsrelated alopecia, which is what Vicky Yu and colleagues' found. Other than the presence of thallium, arsenic, mercury, and selenium, cadmium, bismuth, lithium, and copper should also be taken into account when dermatologists are considering toxic metals as a potential cause of alopecia areata in humans.

c) 2020 S. Karger AG, Basel

To the Editor,

It was a pleasure to read the review article by Vicky Yu and colleagues [1] on the diagnosis of acquired alopecia associated with exposure to toxic metals in humans [1]. In their excellent review of the roles of chemical substances in the pathogenesis of alopecia, the investigators found

karger@karger.com

(c) 2020 S. Karger AG, Basel

www.karger.com/sad

Karger! that some toxic metals - thallium ( $\mathrm{Tl})$, arsenic (As), and mercury $(\mathrm{Hg})$, including the trace element selenium (Se) - can cause alopecia in humans [1]. However, we think that clinicians should also consider other 4 metallic elements in patients with alopecia following acute and/or chronic exposure: cadmium (Cd), bismuth (Bi), copper $(\mathrm{Cu})$, and lithium $(\mathrm{Li})$ [2-4].

In 19 years of surveillance for metals-related diseases in Milan, Italy, a cluster of cases of alopecia areata has been identified in our cohort (25 of 1,376 patients) [5]. We would like to share our experience, for instance, in a cohort of patients with adverse events to dental toxic metals $[5,6]$.

We retrospectively studied 25 consecutive patients with alopecia areata who were seen at a single dental unit (17 of $25,68 \%$ ). The remaining patients ( 8 of $25,32 \%$ ) with confirmed disease were from our Department of Dermatology between 2000 and 2019 (unpublished data). Seven physician-researchers took part. Twenty-four patients (90\%) had alopecia areata. Of the 25 patients, only one had cicatricial (scarring) alopecia (Table 1).

As estimated from previous studies [7-9], the prevalence of alopecia areata worldwide is between 0.57 and $3.8 \%$ [9]. Here, we report the prevalence rate for alopecia 
Table 1. Sex-specific prevalence of alopecia areata and any alopecia related to toxic metal exposure

\begin{tabular}{|c|c|c|c|c|c|c|c|c|c|c|c|c|}
\hline \multicolumn{6}{|c|}{ Alopecia areata } & \multicolumn{6}{|c|}{ Any alopecia } & \multirow{2}{*}{$\begin{array}{l}\text { Worldwide } \\
\text { prevalence }[7,9] \\
\%\end{array}$} \\
\hline $\begin{array}{l}\text { women }^{\mathrm{a}}- \\
\text { prevalence }\end{array}$ & $\%$ & $\begin{array}{l}\text { men - } \\
\text { prevalence }\end{array}$ & $\%$ & $\begin{array}{l}\text { total - } \\
\text { prevalence }\end{array}$ & $\%$ & $\begin{array}{l}\text { women - } \\
\text { prevalence }\end{array}$ & $\%$ & $\begin{array}{l}\text { men }^{\mathrm{b}}- \\
\text { prevalence }\end{array}$ & $\%$ & $\begin{array}{l}\text { total - } \\
\text { prevalence }\end{array}$ & $\%$ & \\
\hline 17 of 24 & 70.83 & 7 of 24 & 29.17 & 24 of 1,376 & 1.74 & 17 of 1,376 & 1.27 & 8 of 1,376 & 0.58 & 25 of 1,376 & 1.82 & $0.57-3.8$ \\
\hline
\end{tabular}

Twenty-five case subjects were determined using 1,376 individuals with adverse events to nonessential metal toxicants. The table shows baseline characteristics of the pilot study cohort. The mean age of the study cohort was 48.9 years (range, 22-74 years) and the cohort contained 17 women (68\%) and 8 men (32\%). a Only 1 patient had combined overexposure to mercury (Hg) and aluminum (Al). This patient, a woman, had been diagnosed with alopecia universalis at 37 years of age. ${ }^{b}$ One isolated case, a 43 -year-old man, categorized clinically as definitely not having alopecia areata, but cicatricial alopecia (scarring alopecia) associated with chronic overexposure to mercury and arsenic was not included in the alopecia areata group.

Table 2. Indications for biochemical studies that should be tailored to the individual patient, according to the degree of zinc deficiency (below the reference range; zinc plasma/serum $<80 \mu$ g per $\mathrm{dL}$ )

\begin{tabular}{lllll}
\hline \multicolumn{2}{l}{ Zinc biomarkers } & & \\
\hline$n$ & $\begin{array}{l}\text { zinc biomarker } \\
\text { (marker name) }\end{array}$ & full name & medium & referent level \\
\hline 1 & ALP & Alkaline phosphatase & Serum & Low/decreased \\
2 & LDH & Lactate dehydrogenase & Serum & Low/decreased \\
3 & AGP & Alpha-1-glycoprotein & Serum & Low/decreased \\
4 & A2M & Alpha-2-macroglobulin & Serum & Low/decreased \\
5 & ALB & Albumin & Serum & Low $/$ decreased \\
6 & TTR & Transthyretin (prealbumin) & Serum & Low/decreased \\
\hline
\end{tabular}

Table 3. Acute and/or chronic exposure to potentially toxic metals as the cause of alopecia areata

\begin{tabular}{llll}
\hline \multicolumn{3}{l}{ Toxic } \\
\hline$n$ & metals associated to alopecia areata & \\
\hline 1 & Aluminum & $\mathrm{Al}$ & references \\
2 & Arsenic & $\mathrm{As}$ & This report \\
3 & Bismuth & $\mathrm{Bi}$ & {$[1,2]$} \\
4 & Cadmium & $\mathrm{Cd}$ & {$[4]$} \\
5 & Copper & $\mathrm{Cu}$ & {$[4]$} \\
6 & Lithium & $\mathrm{Li}$ & {$[2]$} \\
7 & Mercury & $\mathrm{Hg}$ & {$[3]$} \\
8 & Selenium & $\mathrm{Se}$ & {$[2,5,19]$} \\
9 & Thallium & $\mathrm{Tl}$ & {$[1]$} \\
\end{tabular}

areata - in our cohort of patients with adverse health effects to dental toxic metals - which is $1.74 \%(24$ of 1,376$)$ (Table 1). Our prevalence results are similar to that reported in the worldwide literature [9], which has shown that the rates for alopecia areata cases vary widely from 0.57 to $3.8 \%[8,9]$.
Our metal-exposed patients were then confirmed with the use of highly specific laboratory tests (toxicological assessment) $[5,6]$. This observation has been established by a recent immunotoxicology textbook [5].

We noted an association between low serum zinc levels and alopecia areata induced by toxic metals [5]. This finding supports the suggestion that such zinc homeostasis imbalance is the underlying pathophysiologic mechanism for the development of alopecia areata. In our view, zinc depletion has an important role in the development of alopecia areata [10-15]. Therefore, alopecia areata can be attributed to an underlying, long-undiagnosed, zinc deficiency state $[16,17]$. Zinc deficiency in humans was first described by US researchers in the 1970s under the name "conditioned deficiency of zinc" [17]. Dermatologically, the level of zinc was low in plasma/serum and some tissues in newborn infants as well as in children with zinc deficiency who had partial or total hair loss, and dermatitis $[12,14,16,17]$.

Although specific markers of zinc deficiency have not been reported [15-17], we summarized the literature in Table 2. In our experience, biomarkers from blood samples - particularly when lowered initially - may be useful 
for clinical prediction of outcomes (Table 2). There is a risk of primary or secondary malabsorption states, both treatable with zinc repletion (mainly zinc sulfate, $\mathrm{ZnSO}_{4}$ ), that should be considered [15-17].

About mercury, it is important to remember that all forms of mercury compounds (elemental, inorganic, and organic) are able to induce alopecia areata $[5,18,19]$. This may explain why, in the past, there have been cases of alopecia in patients who have been taking intravenous immune globulin injections, containing thimerosal [20].

Our recent reports suggest that mechanisms underlying these hair falls involve acute and/or chronic exposure to toxic metals [5], especially mercury, which could have a varied and widespread influence on the growth of hair (scalp hair), throughout the skin apparatus.

Toxic metals inactivate proteins and may block sulfhydryl cross-linking in keratin (disulfide-linked keratin, Table 3), causing hair loss. Essentially, zinc is replaced by toxic metals through molecular mimicry, substitution, and competition for metabolism in the biological system $[5,17,21]$.
Dermatologists should be aware that patients with alopecia should be carefully monitored for acute and/or chronic exposure to potentially toxic metals.

\section{Disclosure Statement}

The authors have no conflicts of interest to declare.

\section{Funding Sources}

The authors did not receive any funding.

\section{Author Contributions}

P.D.P. designed the work, performed critical revision of the article, and provided final approval of the version to be published; S.M.F. and L.B. carried out data collection; and G.G. performed the statistic interaction and wrote the manuscript with support from P.D.P.

\section{References}

1 Yu V, Juhász $\mathrm{M}$, Chiang A, Atanaskova Mesinkovska N. Alopecia and associated toxic agents: a systematic review. Skin Appendage Disord. 2018 Oct;4(4):245-60.

2 Pierard GE. Toxic effects of metals from the environment on hair growth and structure. J Cutan Pathol. 1979 Aug;6(4):237-42.

3 Silvestri A, Santonastaso P, Paggiarin D. Alopecia areata during lithium therapy. A case report. Gen Hosp Psychiatry. 1988 Jan;10(1): 46-8.

4 Bachanek T, Staroslawska E, Wolanska E, Jarmolinska $\mathrm{K}$. Heavy metal poisoning in glass worker characterised by severe. Ann Agric Environ Med. 2000;7(1):51-3.

5 Guzzi G, Pigatto P. Mercury. Metal allergy: from dermatitis to implant and device failure. New York, USA: Springer; 2018.

6 Pigatto PD, Ronchi A, Bazzigaluppi E, Soldarini A, Barbaro M, Guzzi G. Laboratory features in patients with adverse events to mercury-containing dental amalgam. Toxicol Lett. 2016;258(Suppl 1):s112.

7 Whiting DA. Histopathologic features of alopecia areata: a new look. Arch Dermatol. 2003 Dec;139(12):1555-9.
8 Bhat YJ, Manzoor S, Khan AR, Qayoom S. Trace element levels in alopecia areata. Indian J Dermatol Venereol Leprol. 2009 Jan-Feb; 75(1):29-31.

9 Villasante Fricke AC, Miteva M. Epidemiology and burden of alopecia areata: a systematic review. Clin Cosmet Investig Dermatol. 2015;8:397-403.

10 Alhaj E, Alhaj N, Alhaj NE. Diffuse alopecia in a child due to dietary zinc deficiency. Skinmed. 2007 Jul-Aug;6(4):199-200.

11 Yazbeck N, Muwakkit S, Abboud M, Saab R. Zinc and biotin deficiencies after pancreaticoduodenectomy. Acta Gastroenterol Belg. 2010 Apr-Jun;73(2):283-6.

12 Kil MS, Kim CW, Kim SS. Analysis of serum zinc and copper concentrations in hair loss. Ann Dermatol. 2013 Nov;25(4):405-9.

13 Cheung EJ, Sink JR, English JC III. Vitamin and mineral deficiencies in patients with telogen effluvium: a retrospective cross-sectional study. J Drugs Dermatol. 2016 Oct 1;15(10): 1235-7.

14 Ogawa Y, Kawamura T, Shimada S. Zinc and skin biology. Arch Biochem Biophys. 2016 Dec 1;611:113-9.
15 Aliev G, Li Y, Chubarev VN, Lebedeva SA, Parshina LN, Trofimov BA, et al. Application of acyzol in the context of zinc deficiency and perspectives. Int J Mol Sci. 2019 Apr 29;20(9): 2104.

16 Underwood EJ. Trace elements in human and animal nutrition. 4th ed. New York: Academic Press; 1977.

17 Prasad AS. Trace elements and iron in human metabolism. New York: Plenum Medical Book Co.; 1978.

18 Klobusch J, Rabe T, Gerhard I, Runnebaum B. Schwermetallbelastungen bei patientinnen mit alopezie. Arch Gynecol Obstet. 1993; 254(1-4):278-80.

19 Peters JB, Warren MP. Reversible alopecia associated with high blood mercury levels and early menopause: a report of two cases. Menopause. 2019 Aug;26(8):915-8.

20 Chan-Lam D, Fitzsimons EJ, Douglas WS. Alopecia after immunoglobulin infusion. Lancet. 1987 Jun 20;1(8547):1436.

21 Casarett LJ, Doull J, Klaassen CD. Casarett and doull's toxicology: the basic science of poisons. 6th ed. New York: McGraw-Hill Medical Pub. Division; 2001.

22 Grunfeld O. Thallium poisoning treated with bal. N Engl J Med. 1963 Nov 21;269:1138-40. 